\title{
Access to CRISPR Genome Editing Technologies: Patents, Human Rights and the Public Interest
}

\author{
Duncan Matthews
}

\begin{abstract}
While detailed debates are underway about the scientific and ethical implications of genome editing, this chapter argues that greater attention should be paid to the patent policy issues that these technologies raise. The chapter argues that WTO Members need to consider urgently the implications of patenting genome editing inventions for human rights and the public interest, taking into account Article 27.2 of the TRIPS Agreement, which provides that Members may exclude from patentability inventions, the prevention within their territory of the commercial exploitation of which is necessary to protect ordre public or morality. Furthermore, while genome editing has great potential to transform healthcare and the wellbeing in society across a broad range of scientific fields, the granting of patent rights for these technologies will have profound implications for affordability and access, particularly for people living with chronic lifelong illnesses and for future generations not yet born who are at risk of inheriting preventable medical conditions from their parents. The chapter argues that WTO Members need to consider carefully the impact of granting of genome editing patents, balancing the need to reward inventorship while at the same time having regard to implications for affordability, access and the enjoyment of fundamental human rights.
\end{abstract}

\section{Introduction}

Genome editing technologies hold great potential for scientific research and society. They provide fast, efficient, precise and relatively inexpensive tools to modify the cells of any living organism. Using genome editing techniques, cells of the body (somatic cells) can be modified, potentially curing patients of chronic, lifelong illnesses. Editing the genome of human embryos can also modify the germline identity of human beings, eradicating hereditary diseases in new-born babies and creating resistance to life-threatening conditions for future generations. There is also

\footnotetext{
D. Matthews $(\triangle)$

Queen Mary University of London, London, UK

e-mail: d.n.matthews@qmul.ac.uk 
great potential for non-human uses of genome editing technologies. New varieties of plants can be developed that are disease resistant or have a higher crop yield, while new breeds of farmed animals or marine life can be introduced into the food system in order to offer a broader range of options to consumers and to contribute positively to food security.

The great potential of genome editing is due to the fact that it offers a relatively simple tool to change any organism's deoxyribonucleic acid (DNA). This allows genetic material to be added, removed or altered in particular locations in the genome. Genome editing technologies can be divided into four types: zinc finger nucleases (ZFNs), transcription activator-like effector nucleases (TALENs), meganucleuses and CRISPR (Clustered Regularly Interspaced Short Palindromic Repeats). All four work by inducing a natural cellular repair mechanism designed to repair breakages in DNA but the first three are considered more difficult, less precise and more time-consuming process than CRISPR.

Since 2012, CRISPR has been used in combination with Cas9 (CRISPR associated protein number 9 , which plays a vital role in the natural immunological defence system of the body) to guide and cut DNA, and therefore alter, a cell's genome. It does not fundamentally differ from the previously known genome editing technologies but the additional advantages of the CRISPR-Cas9 system lie in its ability to provide a faster, cheaper, more accurate and more efficient method than other previously known genome editing techniques. ${ }^{1}$ For instance, if there is a mutation in the genome, CRISPR-Cas9 makes it possible to search, delete and even replace it. $^{2}$ A simple analogy would be with a word processor document, whereby the author can search for, delete and replace a typographical error. ${ }^{3}$

Yet genome editing raises new challenges in terms of how governance systems regulate technologies and involves key public policy imperatives, particularly those of human rights, fair and equitable access to the benefits of this new technologies' use, and how governance systems can act in the public interest.

In the patent policy debate on genome editing technologies thus far, preliminary studies have already been undertaken into the patentability of CRISPR-Cas9 inventions under United States (U.S.) law, ${ }^{4}$ while claims have been made that patent law in Europe is already fit for purpose. ${ }^{5}$ Elsewhere, various studies have examined the extent that licensing practices can enable or impede research, ${ }^{6}$ how patent-holding

\footnotetext{
${ }^{1}$ See also National Institutes of Health (NIH), U.S. National Library of Medicine, Your Guide to Understanding Genetic Conditions: What Are Genome Editing and CRISPR-Cas9? https://ghr.nlm. nih.gov/primer/genomicresearch/genomeediting

${ }^{2}$ The human genome is about 300 billion letters long and, so far, scientists have identified approximately 6000 mutations.

${ }^{3}$ This analogy with word processing was used, for example, in the presentation by Feng Zhang (Broad Institute) at the Program on Science, Technology and Society Workshop on Editorial Aspirations: Human Integrity at the Frontiers of Biology, 26-28 April 2017, Harvard University.

${ }^{4}$ Deborah (2017), p. 408; Hannah Mosby (2018), p. 579.

${ }^{5}$ All European Academies (ALLEA) (2016).

${ }^{6}$ Sherkow (2017a), p. 565; McMahon (2020) op. cit. n 6.
} 
universities grant exclusive licences to private companies which stand in as surrogates for the institutions themselves, ${ }^{7}$ and how ethical licensing can be used as a tool of privately driven governance, ${ }^{8}$ with evidence that the private governance function of patents is often overlooked. ${ }^{9}$ Other studies have advocated using international law to facilitate agreement on the governing principles, ${ }^{10}$ particularly to identify appropriate limitations to the CRISPR toolkit. ${ }^{11}$ Elsewhere research exemptions have been advocated as mechanisms to guarantee freedom to operate alongside patent pools, clearing houses and compulsory licences in order to help to facilitate access to patented genome editing technologies. ${ }^{12}$

Rather less attention has been paid to the extent that patents for genome editing technologies can be considered barriers to affordable healthcare that infringe the fundamental rights, particularly the right to health. ${ }^{13}$ Greater attention needs to be paid to the extent that the patent issues that CRISPR-based therapies raise can have adverse implications for public health. ${ }^{14}$

Fair and equitable access to healthcare in the context of the right to health is underpinned by the fundamental principle that everyone should have access to the health services they need, when and where they need them, without suffering financial hardship. ${ }^{15}$ This principle takes as its legal basis Article 25.1 of the Universal Declaration of Human Rights, 1948, which states explicitly that "([E] veryone has the right to a standard of living adequate for the health and well-being of himself and his family, including food, clothing, housing and medical care..." and by Article 12.1 of the United Nations International Covenant on Economic, Social and Cultural Rights, which states that "[T]he States parties to the present Covenant recognize the right of everyone to the enjoyment of the highest attainable standard of physical and mental health". ${ }^{16}$

This chapter will argue that, in debates about the inter-relationship between patents, fair and equitable access to human genome editing, greater attention needs to be paid to human rights approaches, taking into account the public interest. As such the patent system needs to be considered carefully from a human rights perspective when the governance of genome editing is scrutinised. This human

\footnotetext{
${ }^{7}$ Contreras and Sherkow (2017), p. 698.

${ }^{8}$ Guerrini et al. (2017), p. 22.

${ }^{9}$ McMahon (2020), p. 161.

${ }^{10}$ Tsung-Ling (2019), p. 1.

${ }^{11}$ Sadie (2019), p. 1.

${ }^{12}$ Van Overwalle et al. (2006), p. 143.

${ }^{13}$ For a general discussion see on the relationship between patents, access to healthcare and the right to health see Matthews (2015), pp. 496-512.

${ }^{14}$ For a preliminary study see Sherkow (2017b), p. 667.

${ }^{15}$ Health is a fundamental human right. Statement by Dr Tedros Adhanom Ghebreyesus, WHO Director-General, 10 December 2017: https://www.who.int/mediacentre/news/statements/funda mental-human-right/en/.

${ }^{16}$ For further discussion see Matthews (2010), pp. 118-139.
} 
rights approach to the study of patents for genome editing technologies is underdeveloped and, the chapter will argue, must take place if governance institutions are to understand fully the impact of granting of genome editing patents, balancing the need to reward inventorship with affordability, access and the enjoyment of fundamental human rights.

In order to address these issues, the chapter will first provide an explanation of the human genome and how CRISPR-Cas9 genome editing works, highlighting the huge potential genome editing of the germline identity of humans for individuals and for society. The chapter will then turn attention to recent patenting controversies, highlighting the genome editing patent disputes that have already taken place in the U.S. and Europe.

Observed through the lens of recent patent disputes in the U.S. and Europe, the chapter will argue that World Trade Organisation (WTO) Members need to pay greater consideration of the patent policy implications of genome editing. Such consideration is imperative in order to ensure that the granting of private rights can be accommodated on an equitable basis, balanced alongside the need to avoid unnecessary risk (including ordre public and morality exceptions under patent law), taking into account human rights principles, meeting public expectations, ensuring fair and equitable access, and acting in the public interest with regard to these potentially transformational healthcare technologies.

By way of limitation, it should be stated from the outset that this chapter is concerned primarily with editing the human germline, given that this specific application of genome editing technologies accords most closely with (and has most immediacy for) concerns about the patent policy implications in terms of the impacts on society outlined above. While it should be acknowledged that many of the issues considered in this chapter apply equally to somatic therapeutic uses (the cells of the body that are not involved in reproduction) and to agricultural or fisheries food production, germline applications will remain the chapter's primary focus.

\section{The Human Genome}

The human genome is contained in 23 pairs of chromosomes (22 autosomes and 1 pair of sex chromosomes) in a sequence of paired chemical bases that are held together in the long molecules of DNA that are present in almost all the cells of the body. The genome is the complete set of genes-regions of the DNA molecule of varying length that usually encode proteins that perform distinct biological functions-together with interspersed non-coding regions that regulate when the genes are expressed. ${ }^{17}$

\footnotetext{
${ }^{17}$ Nuffield Council on Bioethics, Genome Editing and Human Reproduction: Social and Ethical Issues (2018), p. 7.
} 
Although all people have similar sets of genes, no two people have exactly the same genome. Even the genomes of "identical" (monozygotic) twins may differ owing to errors in DNA replication and somatic mutations, as well as acquired differences in their epigenomes. ${ }^{18}$ Some of the genomic differences between people produce differences in their appearance or in their physiology (known as their "phenotype"), while others have no observable effects. Although genomic differences can be highly significant for the expression of disease-related and other characteristics, many of the differences between people that are observable or medically significant arise from the combined effects of genetic, environmental and biographical factors. The Nuffield Council on Bioethics, for instance, has pointed out that environmental factors can cause changes in genes that may increase susceptibility to cancers. ${ }^{19}$

From time to time, inherited genomic variations result in disease or confer a predisposition to disease. This usually comes about due to small changes in the genome, which may be transmitted to future generations. These changes can affect the production of proteins in cells, as well as the regulatory regions of genes or genes that encode a ribonucleic acid (RNA) product. Inherited genetic conditions include life-limiting conditions such as Duchenne muscular dystrophy and cystic fibrosis. Genetic conditions are also significant causes of infertility, pregnancy loss and neonatal death. ${ }^{20}$ Additionally, even the same genetic mutation can differ significantly in terms of the way it is manifested in the people affected (their "phenotype") and the consequences that this may have for the length or quality of their lives. This is because the function of some genes can be modified by other genes, as well as by environmental factors. In the case of single gene disorders, such as Huntingdon's Disease, it is therefore possible that multiple variants in the same genome affect the associated phenotype. These are sometimes referred to as "modifier genes". ${ }^{21}$

Thus far, over 10,000 single gene disorders have been identified which are associated with an alteration in a region of a single gene that affects the biological function of that gene product. Individually, single gene disorders are usually rare, but collectively they affect at least one in every hundred people born worldwide. Since they can be inherited and because of the way humans have evolved, migrated and

\footnotetext{
${ }^{18}$ The epigenome is a multitude of chemical compounds that can tell the genome what to do. The human genome is the complete assembly of DNA (deoxyribonucleic acid)-about 3 billion base pairs - that makes each individual unique. DNA holds the instructions for building the proteins that carry out a variety of functions in a cell. The epigenome is made up of chemical compounds and proteins that can attach to DNA and direct such actions as turning genes on or off, controlling the production of proteins in particular cells. When epigenomic compounds attach to DNA and modify its function, they are said to have "marked" the genome. These marks do not change the sequence of the DNA. Rather, they change the way cells use the DNA's instructions. The marks are sometimes passed on from cell to cell as cells divide. They also can be passed down from one generation to the next. Source: National Human Genome Research Institute, Epigenomics Fact Sheet: https://www. genome.gov/about-genomics/fact-sheets/Epigenomics-Fact-Sheet.

${ }^{19}$ Nuffield Council on Bioethics (2018), op. cit. n 17, 7.

${ }^{20}$ Zorrilla and Yatsenko (2013), p. 1; Hyde and Schust (2015), p. 5; Wojcik et al. (2018), p. 20.

${ }^{21}$ Nuffield Council on Bioethics (2018), op. cit. n 17, 8.
} 
mixed or, in some cases, become geographically isolated, some genetic disorders tend to be associated with particular ethnic groups.

An example is the blood disorder beta thalassaemia, which occurs more commonly among people of Mediterranean origin; another is sickle cell disease, which is more prevalent in Afro-Caribbean groups. In Europe, one of the most widely known single gene disorders is cystic fibrosis, which arises in children of parents who each have an altered copy of the cystic fibrosis transmembrane conductance regulator gene when the child inherits both mutated alleles. While many genetic disorders are now well understood, many rare genetic disorders have not yet been defined in terms of the genetic mutation responsible. ${ }^{22}$

The Nuffield Council on Bioethics has highlighted the practical consequences of the diffusion of genomics. On the one hand, there will be increasing emphasis in health care on prevention and public health and, on the other, the development of increasingly 'personalised' (and therefore differentiated) medicine. This suggests that, as greater awareness of individuals' susceptibility to illness becomes known through the diffusion of genomics, new obligations will arise for public authorities to provide improved societal conditions (for example, higher-quality environmental standards, such as improved air quality, and equitably provided healthcare). Importantly, knowledge about genomics also raises the question of responsibility on individuals not only for adapting their own behaviour and choosing a suitable lifestyle and a suitable material and social environment, but also, potentially, for selecting a genotype that will be expressed in their future children. ${ }^{23}$

Debates about "designer babies" resulting from genetic interventions into pre-implantation embryos in an attempt to influence the traits that resulting children will have are not new. ${ }^{24}$ However, these debates have been brought more sharply into focus by the relative ease with which CRISPR genome editing techniques can alter the germline identity of human beings. The National Academies of Sciences, Engineering and Medicine 2017 Report on Human Genome Editing, for instance, draws the distinction between restorative intervention that can alleviate suffering caused by genetically inherited diseases on the one hand, and interventions that improve bodily condition or function beyond what is needed to restore or sustain health, such as enhanced sports prowess, on the other hand. ${ }^{25}$

\footnotetext{
${ }^{22}$ Nuffield Council on Bioethics (2018), op. cit. n 17, 8.

${ }^{23}$ Nuffield Council on Bioethics (2018), op. cit. n 17, 13.

${ }^{24}$ See, for instance, Bonnie Steinbock, Designer babies: choosing our children's genes, The Lancet (11 October 2008); Jonietz (2003).

${ }^{25}$ The National Academies of Sciences, Engineering and Medicine, Human Genome Editing: Science, Ethics and Governance, 2017, Consensus Study Report, 145.
} 


\section{The CRISPR-Cas9 Genome Editing Technique}

The transformative potential of CRISPR-Cas9 first came to public attention in 2012 following the publication of a seminal paper published in Science by Jennifer Doudna of University of California Berkeley, Emmanuelle Charpentier, at that time based at Umeå University in Sweden, and their collaborators. ${ }^{26}$ The Science paper demonstrated that CRISPR-Cas 9 can be used to cut and (possibly) edit DNA in vitro. Doudna and Charpentier, and also Feng Zhang and George Church at the Broad Institute (an independent research institute that evolved from a decade of research collaborations among scientists at Harvard University and the Massachusetts Institute of Technology), became the names most closely associated with CRISPR-Cas9, while the parallel work of Virginijus Šikšnys was also recognised along with that of Doudna and Charpentier with their joint award of the Kavli Prize in Nanoscience in 2018.

CRISPR-Cas9 was adapted from a naturally occurring genome editing in the bacterial immune system. The bacterial immune system captures snippets of DNA from invading viruses and uses them to create DNA segments known as CRISPR arrays. ${ }^{27}$ The CRISPR arrays allow the bacteria to remember the viruses and, if the viruses attack again, the bacteria produce RNA segments from the CRISPR arrays to target virus DNA. The bacteria then use Cas9 or a similar enzyme to cut the DNA apart, which disables the virus. ${ }^{28}$

In the context of CRISPR-Cas9 gene editing in the laboratory, bio-scientists are able to create a small piece of RNA with a short "guide" sequence that attaches (binds) to a specific target sequence of DNA in a genome. The RNA also binds to the Cas9 enzyme and guides it to the targeted location. The Cas9 enzyme then cuts the DNA at the targeted location so that the genome editing can take place. ${ }^{29}$ As such, CRISPR-Cas9 has enabled precisely targeted alterations to be performed on DNA sequences in living cells. Working like genetic scissors, the Cas9 nuclease opens both strands of the targeted sequence of DNA to introduce the modification to knock-out the mutation. In this way, genome editing is in effect the ability to develop one-shot genome editing medical treatments. ${ }^{30}$ It is being explored in research on a wide variety of diseases, including single-gene disorders such as cystic fibrosis, haemophilia, Huntingdon's disease and sickle cell anaemia, with possible

\footnotetext{
${ }^{26}$ Jinek et al. (2012), p. 816.

${ }^{27}$ National Institutes of Health (NIH), op. cit. 1.

${ }^{28}$ National Institutes of Health (NIH), op. cit. 1.

${ }^{29}$ The underlying mechanism of CRISPR had also been described previously in Archaea by Francisco Mojica in 1993, who is later said to have coined the term 'CRISPR' in correspondence with a colleague (see: Mojica et al. 1993, pp. 613-621; Davies and Mojica 2018, p. 5) and earlier in bacteria by Ishino and colleagues (see: Ishino et al. 1987, pp. 5429-5433), while the conjunction of CRISPR and CRISPR associate nucleases (CRISPR-Cas) was identified as a proto-immune system from 2007 (see: Barrangou et al. 2007, pp. 1709-1712).

${ }^{30}$ Feng Zhang (Broad Institute), op. cit. n 3.
} 
applications including plant, microbial, animal and human genetic interventions. ${ }^{31}$ Genome editing also holds promise for the treatment and prevention of complex diseases such as cancer, heart disease, mental illness and human immunodeficiency virus (HIV) infection. ${ }^{32}$

In order to allow access to embryos for the purpose of editing them, these would be created in a laboratory using a method of in vitro fertilisation (IVF). Perhaps the most plausible application for this would be cases in which the variant predisposed whoever had it to a clinically recognised disease. In this case, it would be necessary to know before the embryo was created that there was a likelihood of it inheriting the disease-causing variant, such as by screening the prospective parents. For instance, individuals might have been alerted to the possible presence of the variant through having an affected relative and through screening.

However, it is important to recognise the uncertainty that continues to exist about the technical efficacy of the procedures currently available. Of particular concern in this regard is whether CRISPR-Cas9 systems faithfully cleave their intended genomic target without uncontrolled cutting of other sequences ("off-target events") in ways that would make them unsafe for clinical use. The Nuffield Council on Bioethics has also pointed to uncertainty over whether the HDR pathway can be recruited to produce the desired genome change at sufficiently high frequencies for effective clinical use or, if so, how. ${ }^{33}$

There are widespread concerns that CRISPR-based genome editing may result in unintended effects in terms of both off-target effects and mutations of human embryos and of incidental editing. ${ }^{34}$ Kosicki, Tomberg and Bradley, for example, found DNA damage that included deletions of thousands of DNA bases, including at spots far from the edit. ${ }^{35}$ In some instances deletions can silence genes that should be active and, in other instances, activate genes that should be silent, including cancercausing genes. ${ }^{36}$

\footnotetext{
${ }^{31}$ See also Nordberg et al. (2018), pp. 36-83: 37.

${ }^{32}$ National Institutes of Health (NIH), op. cit., n 1.

${ }^{33}$ Nuffield Council on Bioethics (2018), op. cit. n 17, 36. Homology directed repair (HDR) is a naturally occurring nucleic acid repair system that can be used to modify genomes in many organisms, including humans. HDR is initiated by the presence of double strand breaks (DSBs) in DNA.

${ }^{34}$ For the US Food and Drug Administration (FDA), off-target effects would usually be assessed in relation to toxicity of a drug. How the off-target effects of gene editing can be assessed is less clear, given that mutations will perhaps occur two or three generations later.

${ }^{35}$ Kosicki et al. (2018), p. 765.

${ }^{36}$ Sharon Begley, 'Potential DNA damage from CRISPR has been "seriously underestimated" study finds', 16 July 2018, STAT News: https://www.statnews.com/2018/07/16/crispr-potentialdna-damage-underestimated/.
} 


\section{Lulu and Nana: The Chinese Genome-Edited Twins "Immune from HIV"}

Widespread public awareness of the possible negative implications and controversies associated with the use of genome editing to edit the human germline identity became the focus of global attention in November 2018 when a Chinese researcher at the Southern University of Science and Technology of China in Shenzhen, Dr. He Jiankui, revealed at the Second International Summit on Human Genome Editing in Hong Kong that, as a result of his research, he had implanted into a female patient embryos that had been edited to disable the genetic pathway HIV uses to infect cells and twins had been born whose embryonic genomes had been edited. ${ }^{37}$ Dr. He claimed to have disabled a gene called CCR5, which encodes a protein that allows HIV to enter cells. Dr. He was seeking to mimic a mutation that is present in about 6-8\% of the population and which helps to protect them from HIV infection.

Concerns were raised in the scientific community that Dr. He might have inadvertently caused mutations in other parts of the genome, which could have unpredictable health consequences. ${ }^{38}$ If the gene has been disabled, the twin girls born with CCR5 disabled could be vulnerable to other diseases. CCR5, for instance, is already thought to help people fight off, for example, the effects of West Nile virus. $^{39}$

Dr. He was widely condemned by the global scientific community for violating long-standing scientific principles and ethical norms through the application of his research. Subsequently, on 21 January 2019, the Southern University of Science and Technology in Shenzhen announced that Dr. He had been dismissed from his post following an investigation by the Guangdong Health Ministry. ${ }^{40}$ By the end of 2019 a court in Shenzhen had found He and two collaborators guilty of conducting illegal medical practices when they had forged ethical review documents and misled doctors into unknowlingly implanting gene-edited embryos into two women. ${ }^{41}$

\footnotetext{
${ }^{37}$ Cyranoski and Ledford (2018), pp. 607-608, https://www.nature.com/articles/d41586-01807545-0.

${ }^{38}$ Most recently, see Antonio Regalado, MIT Technology Review, December 3, 2019: https://www. technologyreview.com/s/614764/chinas-crispr-babies-read-exclusive-excerpts-he-jiankui-paper/.

${ }^{39}$ Cyranoski and Ledford (2018) op. cit. 37.

${ }^{40}$ Cyranoski and Ledford (2018) op. cit. 37.

${ }^{41}$ Normile (2019).
} 


\section{Patenting the CRISPR-Cas9 Genome Editing Breakthrough}

Doudna, Charpentier and their collaborators were named as co-inventors for U.S. Patent Application No. 13/842,859, filed by the University of California, the University of Vienna and Charpentier on 15 March 2013, with a priority date of 25 May 2012 when the original provisional application was filed at the US Patent and Trademark Office (USPTO). The patent application was particularly broad in scope, listing 155 claims to the general CRISPR technology. ${ }^{4}$

Zhang and Church's Broad Institute patent application to the USPTO, US Patent No. 8,697,359, was filed later with a priority date of 12 December 2012, seven months after the Doudna, Charpentier and collaborators' priority date. The Broad Institute patent was nevertheless deemed eligible for a special accelerated examination track and the patent was issued by the USPTO on 15 April $2014 .^{43}$

The USPTO granted the key patent over the foundational CRISPR technology to the Broad Institute following interference proceedings with the University of California.

The outcome of the USPTO Patent Trial and Appeal Board (PTAB), rendering judgment that there was no interference-in-fact between the claims in interference between the University of California and the Broad Institute. ${ }^{44}$ Broad persuaded the PTAB that the parties claim patentably distinct subject matter, rebutting the presumption of interference. Broad convinced the PTAB that its claims, which were all limited to CRISPR-Cas9 systems in a eukaryotic environment, are not drawn to the same invention as the University of California's, the latter which were all directed to CRISPR-Cas9 systems not restricted to any environment.

Specifically, the evidence showed the PTAB that the invention of such systems in eukaryotic cells would not have been obvious over the invention of CRISPR-Cas9 systems in any environment, including in prokaryotic cells or in vitro, because the ordinary skill in the art would not have reasonably expected a CRISPR-Cas9 system to be successful in a eukaryotic environment. ${ }^{45}$

The PTAB terminated interference proceedings upon accepting Broad's argument that its claims pertaining to eukaryotic cells are sufficiently distinct from the University of California's claims for use in any environment, meaning there was no "interference in fact," a threshold requirement rooted in 37 C.F.R. $§ 41.203$ (a).

\footnotetext{
${ }^{42}$ See also Feldman (2016), p. p. 401.

${ }^{43}$ See also Jacob S. Sherkow, The CRISPR Patent Interference Showdown Is on: How Did We Get Here and What Comes Next? Stanford Law School Law and Biosciences Blog: https://law.stanford. edu/2015/12/29/the-crispr-patent-interference-showdown-is-on-how-did-we-get-here-and-whatcomes-next/.

${ }^{44}$ USPTO Patent Interference No. 106,048. Decisions on Motions 37 C.F.R. $§ 41.125$ (a).

${ }^{45}$ Cyranoski and Ledford (2018) op. cit. 37, 2. See also Kevin Noonan, 'CRISPR Interference Parties Propose Motions', Patent Docs Patent Law Blog, 1 August 2019: https://www.patentdocs. org/2019/08/crispr-interference-parties-propose-motions.html.
} 
The University of California's claims had been based on inventions made by Doudna, Charpentier and their collaborators. As discussed above, their breakthrough research in 2012 had demonstrated that CRISPR-Cas9 can be used to cut and (possibly) edit DNA in vitro. However, the USPTO decided that this did not extend to editing genomes in advanced, or eurkaryotic cells, and as such the Broad Institute's invention was not obvious having regard to the prior art.

Though the PTAB did not cancel or finally refuse any claims when terminating the interference, its decision triggered speculation that UC might eventually take U.S. rights to use in prokaryotes, with Broad taking them in eukaryotes.

The equivalent application by the Broad Institute for European patent was filed at the European Patent Office (EPO) but, on 23 March 2018, the EPO Opposition Division (OD) found that the priority claim is not valid and revoked the patent for lack of novelty. The case was then referred to the EPO Board of Appeal (BoA), which issued its preliminary comments in preparation for Oral Proceedings on 4 November 2019 (T 0844/18).

The key issues for the Oral Proceedings were whether the priority claim of the Broad Institute patent EP2771468 was valid and whether the EPO had the power to decide on entitlement to priority. The patentees appealed the OD Decision and the Oral Proceedings before EPO Board of Appeal 3.3.08 on this critical issue commenced on 13 January 2020.

The opponents to the Broad Institute argued successfully that the EPO is competent to priority and bound to do so by Article 87 of the European Patent Convention (EPC), and that the OD decision was in line with the large body of EPO case law on priority. The EPO case law provides that the right to claim priority from an earlier application according, as set out in Article 87 EPC which itself is derived from Article 4 of the Paris Convention on the Protection of Industrial Property (1967), is afforded to the applicant of the earlier application and to no other party. As such, the applicant (or applicants) must be the same as the original filing. The Broad Institute's European patent EP2771468 was based on a Patent Cooperation Treaty (PCT) filing (WO2014204729) claiming priority from a number of US provisional applications. One of the US provisionals named an inventor-applicant who was not named on the PCT application.

The two earliest priority documents that the Broad Institute was seeking to rely on at the EPO from 12 December 2012 and 2 January 2013 named Luciano Marraffini of Rockefeller University as an inventor-applicant. Marraffini was not an applicant on the later patent and had not assigned priority rights to the Broad Institute. In fact, until mid-2017 the Broad Institute and Rockefeller University were in an inventorship dispute over a number of early CRISPR patents. ${ }^{46}$ The '468 patent was thus revoked in view of an invalid priority claim.

\footnotetext{
${ }^{46}$ Allen \& Overy, Broad Institute CRISPR-Cas9 Patent Revoked in Europe, https://www. allenovery.com/en-gb/global/news-and-insights/publications/broad-institute-crispr-cas9-patentrevoked-in-europe.
} 
Of particular note in this case, was the impressive array of prominent experts who provided expert opinions on behalf of the Broad Institute, including former UK Supreme Court President The Rt. Hon. Lord Neuberger, former UK Lord of Appeal in Ordinary judge The Rt. Hon. Lord Hoffmann, Matrix Chambers barrister Philippe Sands, Emeritus Scientific Member of the Max-Planck-Institute for Innovation and Competition Prof. Dr. Joseph Straus, former chair of an EPO Board of Appeal Dr. Ursula Kinkeldey and Swiss Federal Patent Court Judge Dr. Tobias Bremi. ${ }^{47}$ This list of experts attests to the significance that the Broad Institute placed on the value of the patent at stake and the significance of the legal issue in question.

Despite expectations that the Board of Appeal would refer questions on priority arising in the case to the EPO Enlarged Board of Appeal, in fact the Board of Appeal decided it could sufficiently answer all questions on priority and, as such, upheld the findings of the Opposition Division and dismissed the case on grounds that there was already substantial and consistent body of EPO case law on the matter of priority under Article 87 EPC. Broad will also face further oppositions to EP3009511, which is directed to CRISPR-Cpf1 (now called Cas12a) systems. ${ }^{48}$

At the time of writing, the EPO has so far granted three European patents, all to the University of California, the University of Vienna and Emmanuelle Charpentier, and related to "Methods and compositions for RNA-directed target DNA modification and for RNA-directed modulation of transcription".

The first European patent granted to the Regents of the University of California, the University of Vienna and Emmanuelle Charpentier (EP2800811), concerning the basic CRISPR method, was granted on 7 April 2017. ${ }^{49}$ It claims a DNA-targeting RNA that comprises a targeting sequence and, together with a modifying polypeptide, provides for site-specific modification of a target DNA and/or a polypeptide associated with the target DNA. Opposition Proceedings at the EPO were filed subsequently by seven parties, with oral proceedings taking place on 5-7 February 2020. The outcome of the EPO Opposition Proceedings was, taking account of the amendments made by the patent proprietor during the opposition proceedings, the patent and the invention to which it relates were found to meet the requirements of the EPC. ${ }^{50}$

\footnotetext{
${ }^{47}$ Amy Sandys, EPO Revokes Broad Institute Patent - But it's just the beginning for CRISPR-cas, JUVE Patent, 17 January 2020.

${ }^{48}$ Jef Akst, UC Berkeley Receives CRISPR Patent in Europe, Scientist (March 24, 2017), https:// www.the-scientist.com/?articles.view/articleNo/48987/title/UC-Berkeley-Receives-CRISPR- Pat ent-in-Europe/.

${ }^{49}$ EP2800811: https://register.epo.org/application?number $=\mathrm{EP} 13793997 \& \operatorname{tab}=$ main $\quad$ (accessed 1 December 2019).

${ }^{50}$ Art. 53(c) and Rule 28 objection raised by only one of several opponents against EP2800811. The Opposition Division's provisional opinion was fairly dismissive of the Article 53(c) and Rule 28 objections.
} 
The second European patent, with claims that are directed to compositions and uses of a chimeric version of the Cas9 protein, most often associated with use in regulation of gene expression as opposed to direct editing of the genetic code itself, was granted on 26 January 2018. ${ }^{51}$ Opposition proceedings against the grant of the second European patent have been initiated by four parties, while the most recent European patent for a CRISPR-related invention, which claims methods and compositions of using CRISPR-Cas9 to modify DNA and regulate gene activity in eukaryotic cells, including kits to carry out such work, was granted on 1 March 2019, with the first opponent filing an EPO Opposition almost immediately on 1 April 2019. ${ }^{52}$ At the time of writing, the date for oral proceedings relating to the second and third European patents granted to the Regents of the University of California et al has yet to be set and, overall, this is likely to be a lengthy process.

\section{Excluding Genome Editing Technologies from Patentability}

What is surprising about the cases related to CRISPR-Cas9 genome editing that have been considered thus far at the USPTO and EPO is the lack of consideration of the necessity test in decisions to grant patents on these foundational technologies. The Agreement on Trade-Related Aspects of Intellectual Property (the TRIPS Agreement) introduces a "necessity test" to assess whether protection of an overriding social interest is justified. ${ }^{53}$ Specifically, Article 27.2 permits World Trade Organisation (WTO) Members to "exclude from patentability inventions, the prevention within their territory of the commercial exploitation of which is necessary to protect ordre public or morality, including to protect human, animal or plant life or health or to avoid serious prejudice to the environment, provided that such exclusion is not made merely because the exploitation is prohibited by their law".

As is often stressed, a patent is a grant of exclusive rights but not in itself an authorisation to exploit the patented invention. The latter can be regulated by separate legislation provided this is consistent with Article 27.2, including on grounds that it is necessary to protect human, animal or plant life or health or to avoid serious prejudice to the environment. ${ }^{54}$ The flexibility of WTO Members to exclude patents, for example on inventions related to genome editing technologies, therefore is provided for explicitly in the TRIPS Agreement.

The TRIPS flexibilities contained in Article 27.2 reflect the "necessity test" under the evolving jurisprudence of the WTO whereby the national regulatory autonomy constitutes a core principle for WTO Members which are entitled to pursue their

\footnotetext{
${ }^{51}$ EP3241902: https://register.epo.org/application?number=EP17163434\&tab=main.

${ }^{52} \mathrm{EP} 3401400: \mathrm{https}: / /$ register.epo.org/application?number $=\mathrm{EP} 18152360$.

${ }^{53}$ See also UNCTAD-ICTSD Project on IPRs and Sustainable Development (2005), p. 378.

${ }^{54}$ Ibid., page 382-383.
} 
domestic policy objectives and choose the means for their fulfilment, provided they do not entail protectionist ends. ${ }^{55}$ The necessity test also underpins the principles set out in Article 8.1 of the TRIPS Agreement, whereby "Members may, in formulating or amending their laws and regulations, adopt measures necessary to protect public health and nutrition, and to promote the public interest in sectors of vital importance to their socio-economic and technological development, provided that such measures are consistent with the provisions of this Agreement."

The scope of Article 8.1 was elaborated on by the WTO Dispute Settlement Panel Report in Canada-Patent Protection of Pharmaceutical Products, whereby the prohibition on discrimination as to the field of technology contained in Article 27.1 of TRIPS "does not limit the ability to target certain products in dealing with certain of the important national policies referred to [in Article 8.1]." ${ }^{, 56}$ The Panel therefore confirmed that there is considerable scope for WTO Members to include in national legislation exclusions based on measures necessary to protect health and to promote the public interest as set out in the permissible ordre public or morality exceptions set out in Article 27.2 of TRIPS.

With regard to the application of the TRIPS flexibilities available under Articles 8.1 and 27.2 of TRIPS in the U.S., it is widely understood that there are no restrictions on patentable subject matter under Section 101 of the U.S.C., and hence no immediate grounds for the USPTO to refuse CRISPR-Cas9 genome editing patents using Article 27.2 type ordre public or morality exceptions to patentability. This legal position was subject to confirmatory judgment by the U.S. Supreme Court in Diamond v. Chakrabarty, with the seminal conclusion that statutory subject matter under 101 includes "everything under the sun that is made by man". 57

The situation differs in Europe, where the patentability of inventions related to the editing of germline genomes is already restricted in EPC countries, exceptions to patents being directly linked and based on the logic of inserting public policy mechanisms in patent law. ${ }^{58}$ When these public policy mechanisms are applied to the grant of patents in the field of the life sciences, and particularly in reproductive medicine and genetic engineering, the debate has been controversial for decades. ${ }^{59}$

Article 53(a) of the EPC sets out a general ordre public and morality exception whereby "European patents shall not be granted in respect of ... inventions the publication or exploitation of which would be contrary to 'ordre public' or morality, provided that the exploitation shall not be deemed to be contrary merely because it is prohibited by law or regulation in some or all of the Contracting States".

The meaning of ordre public in the context of Article 53(a) EPC has since been elaborated by the EPO Technical Board of Appeal in the T356/93 decision as

\footnotetext{
${ }^{55}$ Kapterian (2010), pp. 89-127; Salinas Alcaraz (2015), pp. 77-99.

${ }^{56}$ Canada - Patent Protection of Pharmaceutical Products, Report of the Panel, WT/DS114/R, 17 March 2000, paragraph 7.92.

${ }^{57}$ Diamond v. Chakrabarty 447 U.S. 303 (1980).

${ }^{58}$ Nordberg et al. (2018) op. cit. n 31, 40.

${ }^{59}$ For a wider discussion see Ingrid SchneiderLL (2019), pp. 263-287.
} 
follows: "It is generally accepted that the concept of 'ordre public' covers the protection of public security and the physical integrity of individuals as part of society. This concept encompasses also the protection of the environment. Accordingly, under Article 53(a) EPC, inventions the exploitation of which is likely to breach public peace or social order (for example, through acts of terrorism) or to seriously prejudice the environment are to be excluded from patentability as being contrary to 'ordre public'."

In the same T 356/93 decision, the EPO Technical Board of Appeal elaborated on the meaning of "morality" under Article 53(a) EPC as follows: "The concept of morality is related to the belief that some behaviour is right and acceptable whereas other behaviour is wrong, this belief being founded on the totality of the accepted norms which are deeply rooted in a particular culture. For the purposes of the EPC the culture in question is the culture inherent in European society and civilisation. Accordingly, under Article 53(a) EPC, inventions the exploitation of which is not in conformity with the conventionally accepted standards of conduct pertaining to this culture are to be excluded from patentability as being contrary to morality."

The EPO Guidelines for Examination on Article 53(a) EPC also elaborate on how the test should be applied: "Any invention the commercial exploitation of which would be contrary to 'ordre public' or morality is specifically excluded from patentability. The purpose of this is to deny protection to inventions likely to induce riot or public disorder, or to lead to criminal or other generally offensive behaviour ... Anti-personnel mines are an obvious example. This provision is likely to be invoked only in rare and extreme cases. A fair test to apply is to consider whether it is probable that the public in general would regard the invention as so abhorrent that the grant of patent rights would be inconceivable. If it is clear that this is the case, objection should be raised under Art. 53(a); otherwise not. ..". ${ }^{61}$

In the EU law context there are explicit links with the ordre public and morality exceptions of Article 53(a) EPC by means of the 1998 Biotechnology Directive. ${ }^{62}$ The Directive includes, in Articles 5 and 6, provisions which can be interpreted as having the aim of preserving European fundamental values and human rights norms in patent law. ${ }^{63}$

Article 5 of the Biotechnology Directive focuses on the human body which, at various stages of its formation and development, and the simple discovery of one of its elements, including the sequence or partial sequence of a gene, cannot constitute patentable inventions. Nevertheless, Article 5 goes on to state that an element isolated from the human body or otherwise produced by means of a technical process, including the sequence or partial sequence of a gene, may constitute a

\footnotetext{
${ }^{60}$ EPO Technical Board of Appeal in Plant Genetic Systems/Glutamine synthetase inhibitors T356/ 93 [1995] EPOR 357.

${ }^{61}$ Guidelines for Examination in the EPO C-IV, 4.1.

${ }^{62}$ Directive 98/44 of the European Parliament and of the Council of 6 July 1998 on the Legal Protection of Biotechnological Inventions.

${ }^{63}$ Schneider, op. cit. n 58 .
} 
patentable invention, even if the structure of that element is identical to a natural element, provided that the industrial application of a sequence or a partial sequence of a gene is disclosed in the patent application.

The sixteenth recital to the Biotechnology Directive indicates that the logic of Article 5 is "respect for the fundamental principles safeguarding the dignity and integrity of the person", asserting that "it is important to assert the principle that the human body, at any stage in its formation or development, including germ cells and the simple discovery of one of its elements or one of its products, including the sequence or partial sequence of the human gene, cannot be patented". ${ }^{64}$

Article 6(1) of the Biotechnology Directive then goes on to require that "inventions shall be considered unpatentable where their commercial exploitation would be contrary to ordre public or morality", while Article 6(2) sets out a non-exhaustive list of examples of biotechnological inventions that are excluded from patentability on moral grounds, including (a) "processes for cloning human beings", (b) "processes for modifying the germ line genetic identity of human beings", and (c) "uses of human embryos for industrial or commercial purposes".

Nevertheless, Article 6(1) of the Biotechnology Directive should be read in conjunction with Recital 42, which states that “... in any case such exclusion does not affect inventions for therapeutic or diagnostic purposes which are applied to the human embryo and are useful to it". Whether genome editing techniques comprising processes for modifying the germline genetic identity of human beings constitute inventions for "therapeutic" purposes within the meaning of Recital 42 therefore remains uncertain and is yet to be clarified by the EPO or its Boards of Appeal.

In this regard, it should be noted that although the EPO, as an organisation constituted by the EPC, is not subject to the treaties and legislation of the EU, the EPO Administrative Council adopted all the articles of the Biotechnology Directive into its own legal order via the implementing rules of the EPC, with Articles 5 and 6 of the Biotechnology Directive comprising Rules 28 and 29 of the EPC. ${ }^{65}$

Consequently, Rule 28 of the Implementing Regulations to the EPC imports the Article 6(2)(b) provision of the Biotechnology Directive into EPO examination practice whereby "Under Article 53(a) EPC European patents shall not be granted in respect of biotechnological inventions which, in particular, concern: ... (b) processes for modifying the germ line genetic identity of human beings...". The possibility that Recital 42 of the Biotechnology Directive could over-ride the exception to the patentability of genome editing technologies for processes related to modifying the germline genetic identity of human beings therefore remains remote before the EPO.

\footnotetext{
${ }^{64}$ See also Schellekens and Vantsiouri (2013), p. 190: https://www.tandfonline.com/doi/abs/10. 5235/17579961.5.2.190, who elaborate on the concept of human dignity and refer to Marco Olivetti's commentary on Article 1 of the EU Charter of Fundamental Rights, in which he 'discerns human beings becoming mere objects in medical or biological practices as an example of an affront to dignity' (Olivetti 2010, p. 7).

${ }^{65}$ See also Schneider, op. cit., n 58, 264.
} 
Rule 29 of the Implementing Regulations is also directly relevant to genome editing technologies relating to the human germline given that it states, in Rule 29.1, that " $\mathrm{t}]$ he human body, at the various stages of its formation and development, and the simple discovery of one of its elements, including the sequence or partial sequence of a gene, cannot constitute patentable inventions".

Nevertheless, the debate remains ongoing as to whether the exclusions to patentability encompassed in Articles 5 and 6 of the Biotechnology Directive and, by association, Rules 28 and 29 of the Implementing Regulations to the EPC embody the precautionary principle as enshrined in Article 191 of the Treaty on the Functioning of the European Union (TFEU) which aims at ensuring a higher level of environmental protection through preventative decision-taking in the case of risk. In practice, the scope of the principle is far wider and covers also consumer policy, as well as EU legislation concerning food and human, animal and plant health. ${ }^{66}$ Whether the precautionary principle should (or could) also be taken into account by patent granting authorities when determining whether a European patent should be issued remains, as yet, unresolved. ${ }^{67}$

As demonstrated by the foregoing discussion, the European patent system therefore comprises a fairly comprehensive toolkit to enable patent examiners to assess what types of inventions should be excluded from patentability on grounds that they are considered socially undesirable and/or violate human dignity. ${ }^{68}$ This has a perceptible impact on the drafting of CRISPR-related patent applications to the EPO, with disclaimers such as "non-human', "human germline not modified" or "wherein the cells are not germ cells". ${ }^{69}$

Specifically, although European patent claims to the "composition" or "vector system" (that is to say a DNA molecule used as a vehicle to artificially carry foreign genetic material into another cell) are regularly being granted by the EPO, on grounds that they are considered to fall outside the Rule 28(b) exception, there is significant evidence of amendments to the claims in genome editing European patent applications which explicitly exclude use of a process for modifying the germline genetic identity of human beings. ${ }^{70}$

\footnotetext{
${ }^{66}$ European Commission, Communication $(\mathrm{COM}(2000) 1$ final) on the Precautionary Principle: https://eur-lex.europa.eu/legal-content/EN/TXT/?uri=LEGISSUM\%3Al32042.

${ }^{67}$ See, for instance, Reynolds (2013), p. 95; Nordberg et al. (2018), op. cit. 31, 49-50, noting that in its most simple formulation the Precautionary Principle may seem to ignore the costs of not continuing a line of research and development and finding that, while a broadly precautionary approach to regulation of gene editing is justified, it is important that it is interpreted in a way that avoids a disproportionate (and potentially incoherent) focus on possible harm. Nordberg et al. (2018) op. cit. n 31, sum up that CRISPR-Cas9 and the future of gene-editing technology can potentially produce enormous benefits to humans, but the uncertainty about possible harm that may result from large-scale gene editing means that a precautionary approach is advisable to policy decisions that respect a proportionality constraint on acceptable precautions.

${ }^{68}$ See also Schneider, op. cit. n 58, 267.

${ }^{69}$ See also Schneider, op. cit. n 58, 283.

${ }^{70}$ Sherkow and Thomas Scott (2019), p. 97 North Carolina Law Review 1497, discusses the strategy of keeping some of the most significant information about vectors secret while patenting only certain aspects.
} 
A practical example of limitations to claim language introduced by the EPO Examining Division is the aforementioned Broad Institute European patent EP2771468, which was subject to Oral Proceedings at the EPO in January 2020. The Broad Institute patent contained amended claim language relating to "Use of the composition of claim 1, or the vector system of claim 2 or any claim dependent thereon for genome engineering, provided that said use is not a method for treatment of the human or animal body by surgery or therapy, and provided that said use is not a process for modifying the germline genetic identity of human beings" [emphasis added]. This amended claim language is, of course, consistent with both Rule 28 of the Implementing Regulations to the EPC and Article 6(2)(b) the Biotechnology Directive.

Indications that limiting claim language into European patents for CRISPR technologies is being established as office practice at the EPO is supported by closer examination of the Regents of the University of California, University of Vienna, Emmanuelle Charpentier European patent EP2800811. The University of California et al patent contains similar amended language to the Broad Institute ' 468 patent. Specifically, the ' 811 patent at claims 20 and 21 states: "provided that said method is not a method of modifying the germ line identity of a human being" [emphasis added], this wording being upheld during EPO Oral Proceedings on 5-7 February 2020.

It is certainly significant that the limiting claim language to the " 468 and ' 811 patents are very similar, indicating a practice for the EPO Examining Division to insert Rule 28 type language in all such cases. The approach taken in the '468 and '811 patents is also consistent with findings of the All European Academies (ALLEA) Statement on Patent-Related Aspects of CRISPR-Cas Technology which, in 2016, considered the principles enshrined in the EU Biotechnology Directive and the Implementing Regulations of the EPC, as applied in the patent grant practice of the EPO to inventions related to CRISPR technology, fit for purpose and flexible enough to take account of future regulatory developments.

Such limitations on patent claims (or refusal to grant a patent based on morality exceptions) have raised concerns that such a policy may result in a chain reaction of overall reduction in the various types of incentives to innovate and invest in the areas of research concerned. ${ }^{71}$ No doubt such concerns will continue to be raised and limitations to claim language for European patents related to genome editing technologies will remain under close scrutiny in the future.

\footnotetext{
${ }^{71}$ See, for instance, Nordberg et al. (2018), op. cit. n 31, 51.
} 


\section{International Human Rights Law and Genome Editing}

We now turn in this chapter to the implications of granting patents relating to genome editing in terms of the enjoyment of internationally binding human rights. The applicable international and legally binding instrument dealing specifically with the protection of human rights in the biomedical field is the Oviedo Convention. ${ }^{72}$

The Oviedo Convention draws on the principles established by Article 1 of the Universal Declaration on Human Rights (UDHR) of 1948, which affirms that "[a]11 human beings are born free and equal in dignity and rights."

As the Nuffield Council on Bioethics has acknowledged, dignity is an important concept that links human beings to the possession of a human genome and, at the same time, elevates the being of individual humans above the given. ${ }^{73}$ Dignity also plays a restraining role. For example, the UNESCO Declaration on Science and the Use of Scientific Knowledge affirms specifically that both "scientific research and the use of scientific knowledge should respect human rights and the dignity of human beings., 74

The Oviedo Convention aims to protect the dignity and identity of all human beings and guarantee everyone, without discrimination, respect for their integrity and other rights and fundamental freedoms with regard to the application of biology and medicine. It set out fundamental principles applicable to daily medical practice and is regarded as establishing basic patient's rights. It also deals with biomedical research, genetics and transplantation of organ and tissues. ${ }^{75}$

Specifically, Article 13 of the Oviedo Convention (entitled 'Interventions on the human genome') prohibits germline modification: "An intervention seeking to modify the human genome may only be undertaken for preventive, diagnostic or therapeutic purposes and only if its aim is not to introduce any modification in the genome of any descendants."

Article 13 therefore establishes two key principles. First, that any genome modification (in research or in treatment) should have as its aim a benefit for human health. It does not permit genome modifications that are for other purposes. For example, it does not permit attempts to enhance human characteristics beyond normal functioning or for welfare purposes not related to health. For those states in which the Oviedo Convention is in force, Article 13 therefore limits, but does not prohibit, genome editing involving human embryos for research purposes. Second,

\footnotetext{
${ }^{72}$ Convention for the Protection of Human Rights and Dignity of the Human Being with regard to the Application of Biology and Medicine: Convention on Human Rights and Biomedicine (ETS No 164).

${ }^{73}$ Nuffield Council on Bioethics (2018), op. cit. n 17, 124.

${ }^{74}$ UNESCO Declaration on Science and the Use of Scientific Knowledge (1999), Preamble, para. 19. The UNESCO Declaration on Bioethics and Human Rights asserts that the "ethical issues raised by the rapid advances in science and their technological applications should be examined with due respect to the dignity of the human person...".

${ }^{75}$ Oviedo Convention and its Protocols, Council of Europe, opened for signature on 4 April 1997, Oviedo, Spain: https://www.coe.int/en/web/bioethics/oviedo-convention.
} 
the aim must not be to introduce changes that can be passed on to future generations; that is, interventions that lead to the birth of children with a modified genome. ${ }^{76}$

On the face of it, Article 13 of the Oviedo Convention appears to prohibit heritable genome editing interventions although, according to the Nuffield Council on Bioethics, not without some ambiguity. ${ }^{77}$ However, it has been argued persuasively that the Convention does not veto genetic editing for basic research purposes, but only its clinical application on human embryos to be transferred into the womb. ${ }^{78}$ This argument is supported by the strict textual interpretation of the Convention, given that Article 13 states explicitly that "An intervention seeking to modify the human genome may only be undertaken for preventive, diagnostic or therapeutic purposes and only if its aim is not to introduce any modification in the genome of any descendants" [emphasis added].

The prohibition introduced by Article 13 of the Oviedo Convention therefore appears limited to interventions seeking to modify the human genome only where this introduces modifications into the genome of descendants. As such, the wording of Article 13 can be interpreted as giving sufficient room for basic research into preventive, diagnostic or therapeutic purposes. ${ }^{79}$ Nevertheless, it should also be borne in mind that the explanatory report to the Convention refers explicitly to the need to "protect the dignity and identity of all human beings", ${ }^{80}$ underpinned by the guiding principle of the primacy of the human being. ${ }^{81}$

Although the Oviedo Convention is the only international legal instrument that explicitly addresses heritable genetic modification, even those countries that have not signed or ratified the Convention, including the UK and Germany, have taken it into account in framing their domestic provisions in many areas of biomedicine such as patient rights, consent and privacy, the protection of biomedical research participants or living donors and in relation to applications of biomedicine such as genetics. $^{82}$

\footnotetext{
${ }^{76}$ See also Nuffield Council on Bioethics (2018), op. cit. n 17, 117.

${ }^{77}$ Nuffield Council on Bioethics (2018), op. cit. 17, 124.

${ }^{78}$ de Mignuel Beriain et al. (2019), p. 226.

${ }^{79}$ Ibid, 229.

${ }^{80}$ 'In every case, any intervention which aims to modify the human genome must be carried out for preventive, diagnostic or therapeutic purposes. Interventions aimed at modifying genetic characteristics not related to a disease or to ailment are prohibited. As long as somatic cell gene therapy is currently at the research stage, its application can be allowed only if it complies with the standards of protection provided for in Article 15 and the following Articles'. Paragraph 90, Explanatory Report to the Convention for the Protection of Human Rights and Dignity of the Human Being with regard to the Application of Biology and Medicine: Convention on Human Rights and Biomedicine', Oviedo, 4.IV.1997, European Treaty Series No. 164, Council of Europe: https://rm.coe.int/ 16800ccde5. See also Nordberg (2018), pp. 54-92: 77.

${ }^{81}$ The whole Convention, the aim of which is to protect human rights and dignity, is inspired by the principle of the primacy of the human being, and all its articles must be interpreted in this light'. Paragraph 22, Explanatory Report to the Convention, ibid.

${ }^{82}$ See also Nuffield Council on Bioethics (2018) op. cit. n 17, 116.
} 
Elsewhere, in the scientific community, the wider debate on whether there should be a complete ban on gene editing technologies continues and remains largely polarised. ${ }^{83}$ Central to this wider debate are arguments that the Oviedo Convention, as currently worded, prioritises human rights and human dignity over the interests of scientific endeavour and technological needs. ${ }^{84}$ This emphasis on human rights and human dignity is consistent with Article 3 of the EU Charter of Fundamental Rights, which protects the right to respect for a person's physical and mental integrity. ${ }^{85}$ Paragraph 1 of the Charter asserts that "everyone has the right to respect for his or her physical and mental integrity", while paragraph 2 sets out a not exhaustive list of acts that must be respected in particular in the fields of medicine and biology, namely: (a) the free and informed consent of the person concerned, according to the procedures laid down by law; (b) the prohibition of eugenic practices, in particular those aiming at the selection of persons; (c) the prohibition on making the human body and its parts as such a source of financial gain; and (d) the prohibition of the reproductive cloning of human beings.

\section{International Initiatives on the Regulation and Governance of Gene Editing}

International initiatives lead by the scientific community have also played an important role to play in framing the debate on access to gene editing technologies and allaying fears of a eugenic future. ${ }^{86}$ Persistent calls have been made for an international moratorium on gene editing. ${ }^{87}$ In March 2015, many of the eminent scientists working at the cutting-edge of CRISPR research co-authored a statement published in Science magazine calling for a moratorium on germline cell editing. ${ }^{88}$

Elsewhere, the US National Academies of Science and National Academy of Medicine Human Gene-Editing initiative, designed to inform decision-making related to recent advances in human genome-editing research, has been a particularly

\footnotetext{
${ }^{83}$ See, for example, the counter arguments in Sykora and Caplan (2017), pp. 1871-1872, who argue that the debate cannot occur while scientists and clinicians forge ahead with germline modifications and disregard the views, interests and concerns of the many communities to whom germline modification matters; and Baylis and Ikemoto (2017), pp. 2084-2085.

${ }^{84}$ Baylis and Ikemoto (2017) ibid 2084.

${ }^{85}$ Charter of Fundamental Rights of the European Union (2010/ C 83/389: https://eur-lex.europa.eu/ LexUriServ/LexUriServ.do?uri=OJ:C:2010:083:0389:0403:en:PDF.

${ }^{86}$ Nordberg et al. (2018), op. cit. n 31, 39.

${ }^{87}$ See, for example, Schneider, above, n 58, 281, citing Baltimore et al. (2015a), pp. 36-38; Lanphier et al. (2015), pp. 410-411; Leopoldina Nationale Akademie der Wissenschaften, The Opportunities and Limits of Genome Editing (2015): https:/www.leopoldina.org/en/publications/ detailview/publication/chancen-und-grenzen-des-genome-editing-2015/; Reich et al. (2015).

${ }^{88}$ Baltimore et al. (2015b), pp. 365-338: https://www.ncbi.nlm.nih.gov/pmc/articles/ PMC4394183/.
} 
valuable venue for international dialogue. ${ }^{89}$ The First International Summit on Gene Editing took place in Washington DC on 1-3 December 2015, hosted by the National Academy of Sciences and the National Academy of Medicine and co-hosted by the Chinese Academy of Sciences and the UK Royal Society. The Summit convened experts from around the world to discuss the scientific, ethical, and governance issues associated with human gene-editing research. A Second International Summit on Human Genome Editing took place in Hong Kong on 27-29 November 2018, hosted by the Academy of Sciences of Hong Kong in collaboration with the UK Royal Society, the US National Academy of Sciences and the US Academy of Medicine.

Subsequently, on 13 August 2019, the first public meeting on the International Commission on the Clinical Use of Human Germline Genome Editing took place in Washington DC, hosted by the National Academy of Sciences, with the second meeting of the Commission taking place in London on 14-15 November 2019 and hosted by the Royal Society.

The World Health Organization (WHO) is also playing an increasing active role in coordinating global policy responses to CRISPR genome editing worldwide. On 14 December 2018 the WHO announced the establishment of an 18-member multidisciplinary Expert Advisory Committee on the Governance and Oversight of Human Genome Editing to examine the scientific, ethical, social and legal challenges associated with human genome editing (both somatic and germ cell). ${ }^{90}$ The committee sought to identify regulatory and governance gaps, concerns about inappropriate use of human genome editing technologies and concerns regarding rogue clinics exploiting regulatory gaps in some parts of the world. On 29 August 2019 the WHO expert advisory committee announced that it had approved the first phase of a new global registry to track research on human genome editing, using the International Clinical Trials Registry Platform (ICTRP), a WHO entity. ${ }^{91}$

On 12 July 2021 the WHO Expert Advisory Committee on the Governance and Oversight of Human Genome Editing published its final reports entitled Human Genome Editing: A Framework for Governance and Recommendations. The Committee's Framework for Governance elaborates why a governance role for patents can be significant, acknowledging that patent holders may find themselves with a reasonable amount of influence over how a technology develops. Likewise, the Committee's Recommendations recognise the practical considerations in terms of relevant patent holders perhaps being unwilling to limit the use of their inventions, and the unequal geographic distribution of patent holders given the location of current patent applications relevant to human genome editing. To implement these

\footnotetext{
${ }^{89}$ National Academies of Sciences Human Genome Editing Initiative: https://nationalacademies. org/gene-editing/index.htm.

${ }^{90}$ Global health ethics: Human Genome editing, World Health Organization: https://www.who.int/ ethics/topics/human-genome-editing/en/.

${ }^{91}$ WHO Launches Global Registry on Human Genome Editing, World Health Organization, 29 August 2019: https://www.who.int/news-room/detail/29-08-2019-who-launches-global-regis try-on-human-genome-editing.
} 
actions, the specific Recommendations of the Committee are: first, in collaboration with other international institutions, such as the World Intellectual Property Organization (WIPO), the WTO and its TRIPS Agreement, that the WHO should encourage relevant patent holders to help ensure equitable access to human genome editing interventions; second, that the WHO should encourage industry to work with resource-constrained countries to build capacity to take advantage of human genome interventions; and, third, that the WHO should convene a meeting of those holding or applying for patents relevant to human genome editing, industry bodies, international organisations such as WIPO and the WTO, and those involved in establishing or running relevant patent pools to explore the potential for the adoption of appropriate ethical licensing requirements.

WHO Expert Advisory Committee's Recommendations on intellectual property comprise one of eight core themes on the governance of human genome editing and have been subject to careful analysis by patent scholars (including the author of this chapter). This patent scholars' analysis builds upon and elaborates the Committee's work, in particular by calling for wider public debate about the role of "ordre public" or morality exceptions to patentability in the area of genome editing or considering promoting post-grant governance through the use of research exceptions or compulsory licences. ${ }^{92}$

The WHO has also called for a moratorium, emphasising that countries should not allow any further work on human germline genome editing in human clinical applications until the technical and ethical implications have been properly considered. ${ }^{93}$ Such further work is considered, at this time, to be inconsistent with the principle of responsible stewardship of science. ${ }^{94}$

\section{Concluding Remarks}

CRISPR genome editing interventions have great potential to edit the germline human identity in a manner which will eliminate diseases, improve public health and contribute positively to welfare in society. Yet genome editing also poses unique and unprecedented challenges: scientific, regulatory and ethical. The potential uses of these technologies to alter the human germline raise a number of fundamental issues for society. Editing of the human genome will influence the characteristics of

\footnotetext{
${ }^{92}$ Matthews et al. (2021).

${ }^{93}$ WHO Launches Global Registry on Human Genome Editing, World Health Organization, 29 August 2019: https://www.who.int/news-room/detail/29-08-2019-who-launches-global-regis try-on-human-genome-editing.

${ }^{94}$ Presentation by Robin Lovell Badge (Francis Crick Institute, UK), member of the WHO expert advisory committee on developing global standards for governance and oversight of Human Genome editing at the Second Meeting of the International Commission on the Clinical Use of Human Germline Genome Editing, London, 14 November 2019. Available at: https://royalsociety. org/topics-policy/projects/genetic-technologies/international-commission/.
} 
future generations in ways that may well be considered ethically unacceptable given the unknown risks of off-target effects. Ensuring that institutions are appropriately equipped to accommodate this new technology is essential for the future governance and regulation of gene editing technologies, of which the patent system forms a crucial component part.

The risks, benefits and ethical reasoning for exclusions to patentability need to be considered carefully by the policy community, based on inputs from all stakeholders, including patient groups, the scientific community and also those engaged in patent law and policy. As has been argued convincingly, it is only through public policy engaging multiple stakeholders and the interdisciplinary academic community that dialog proceeds in a manner that is conducive to the future development of this ground-breaking technology. ${ }^{95}$ This imperative applies to the patent system as much as it does to other levers of governance and regulation.

In this context, WTO Members should pay careful attention to the patent policy implications of genome editing technologies, particularly for inventions relating to altering the germline identity of human beings. Strong arguments can be made in favour of encouraging such inventions in terms of eradicating hereditary diseases in new-born babies and creating resistance to life-threatening conditions for future generations. Such uses of genome editing technologies may well be considered consistent with fundamental human rights, particularly the right to dignity, of future generations under Article 13 of the Oviedo Convention.

Nonetheless, WTO Members must balance decisions about permitting the patenting of this transformational technology and the possibilities of eradicating, for example certain hereditary diseases from society, with the possibilities of negative impacts when deciding to permit patents on altering the germline identity of human beings. The extent of off-target effects for future generations, effects that are ancillary to the intended genome alteration, are not yet known or fully understood. The shadow of eugenics experiments conducted in Europe during the middle of the last century remains strong. Human rights, particularly those enshrined in Article 13 of the Oviedo Convention, must be given primacy at all costs.

The patent system can, and should, play an important role in this process. As we have seen in this chapter, Article 27.2 of the TRIPS Agreement establishes a "necessity test" and encompasses the TRIPS flexibility that WTO Members may exclude from patentability within their territory inventions, the commercial exploitation of which could be considered contrary to ordre public and morality, including to protect human animal or plant life or to avoid serious prejudice to the environment, provided that such exclusion is not made merely because the exploitation is prohibited by their law.

The approach now being taken by the EPO is instructive in this respect. By eschewing an approach based on rejecting CRISPR-based patent applications outright in favour of a more nuanced approach when considering the European patent claim language of genome editing technologies with the potential to alter the

\footnotetext{
${ }^{95}$ Nordberg et al. (2018) op. cit. n 31, 46.
} 
germline identity of human beings, the EPO has retained limits on patentability within the established EPC norms on exclusions to patentability. This chapter has set out how the European patent tradition of exclusions to patentability based on ordre public and morality is well-established by virtue of Article 53(a) EPC, Articles 5 and 6 of the Biotechnology Directive and Rule 28 of the Implementing Regulations to the EPC. The chapter has also demonstrated how the EPO is now paying due regard to these provisions by requiring amended claim language for European Patents relating to genome editing technologies. Other WTO Members should take note of this approach and, it is suggested by this chapter, follow suit. This is imperative in order to ensure that the granting of private patent rights can be accommodated on an equitable basis, balanced alongside the need to avoid unnecessary risk (including the morality exception under patent law), take account of human rights, meet public expectations, and act in the public interest with regard to this potentially transformational healthcare technology.

This chapter has set out some of the risks, advantages, ownership issues, ethics and access problems related to genome editing. We saw in this chapter that the right to health carries with it the expectation that everyone should have access to the health services they need, when and where they need them, without suffering financial hardship. This is particularly pertinent given the global context in which access to health care technologies needs to be evaluated. Different IP regimes and the national legislation of different countries express different ethical values. ${ }^{96}$ The world is now only at the beginning of this new healthcare debate and patent systems will be central to how we conceptualise and resolve these public policy problems. Without doubt, given the rapid pace of genome editing science and its wide applications, greater consideration of these crucial issues within the global patent policy community is urgently required if governance institutions are to adequately take into account the impact of granting of genome editing patents, balancing the need to reward inventorship with affordability, access and the enjoyment of fundamental human rights in the public interest.

Acknowledgements With thanks to Emanuela Gambini for invaluable research assistance and insights, and to Phil Hinchliffe, Abbe Brown, Jacob S Sherkow and two anonymous referees for their helpful comments and suggestions. The opinions and any errors in the chapter remain the author's own.

\section{References}

Akst J (2017) UC Berkeley Receives CRISPR Patent in Europe. Scientist (March 24, 2017), https:// www.the-scientist.com/?articles.view/articleNo/48987/title/UC-Berkeley-Receives-CRISPRPatent-in-Europe/ (Last accessed 16 February 2021)

\footnotetext{
${ }^{96}$ Nuffield Council on Bioethics (2018), op. cit. 17, xvi.
} 
All European Academies (ALLEA) (2016) Statement on Patent-Related Aspects of CRISPR-Cas Technology

Allen \& Overy (2021) Broad Institute CRISPR-Cas9 Patent Revoked in Europe, https://www. allenovery.com/en-gb/global/news-and-insights/publications/broad-institute-crispr-cas9-pat ent-revoked-in-europe (Last accessed 16 February 2021)

Baltimore D et al (2015a) A prudent path forward for genomic engineering and germline gene modification. Science 348:36-38

Baltimore D, Berg P, Botchan M, Dana Carroll R, Charo A, Church G, Corn JE, Daley GQ, Doudna JA, Fenner M, Greely HT, Jinek M, Martin GS, Penhoet E, Puck J, Sternberg SH, Weissman JS, Yamamoto KR (2015b) A prudent path forward for genomic engineering and germline gene modification. Science 348(6230):365-338: https://www.ncbi.nlm.nih.gov/pmc/articles/ PMC4394183/ (Last accessed 17 February 2021)

Barrangou R, Fremaux C, Deveau $\mathrm{H}$ et al (2007) CRISPR provides acquired resistance against viruses in prokaryotes. Science 315(5819):1709-1712

Baylis F, Ikemoto L (2017) The Council of Europe and the prohibition on germline genome editing. EMBO Report 18(12):2084-2085

Begley S (2018) Potential DNA damage from CRISPR has been "seriously underestimated" study finds. 16 July 2018, STAT News: https://www.statnews.com/2018/07/16/crispr-potential-dnadamage-underestimated/ (Last accessed 16 February 2021)

Canada - Patent Protection of Pharmaceutical Products, Report of the Panel, WT/DS114/R, 17 March 2000, paragraph 7.92

Charter of Fundamental Rights of the European Union (2010/ C 83/389: https://eur-lex.europa.eu/ LexUriServ/LexUriServ.do?uri=OJ:C:2010:083:0389:0403:en:PDF (Last accessed 16February 2021)

Contreras J, Sherkow JS (2017) CRISPR, surrogate licensing, and scientific discovery. Science 355: (6326)698

Convention for the Protection of Human Rights and Dignity of the Human Being with regard to the Application of Biology and Medicine: Convention on Human Rights and Biomedicine (ETS No 164)

Cyranoski D, Ledford H (2018) Genome-edited baby claim provokes international outcry. Nature 563:607-608, 26 November: https://www.nature.com/articles/d41586-018-07545-0 (Last accessed 16 February 2021)

Davies K, Mojica F (2018) Crazy about CRISPR: an interview with Francisco Mojica. CRISPR J $1: 5$

de Mignuel Beriain I, Armaza EA, Sánchez AD (2019) Human Germline editing is not prohibited by the Oviedo convention: an argument. Med Law Int 19(2-3):226-232, 226

Deborah K (2017) The patentability of the Crispr-Cas9 genome editing tool. Chicago-Kent J Intell Prop 16:408

EP2800811: - Methods and Compositions for RNA-Directed Target DNA Modification and for RNA-Directed Modulation of Transcription. https://register.epo.org/application? number $=E P 13793997 \&$ tab $=$ main $($ Last accessed 16 February 2021)

EP3241902 - Methods and Compositions for RNA-Directed Target DNA Modification and for RNA-Directed Modulation of Transcription. https://register.epo.org/application? number $=E P 17163434 \&$ tab $=$ main (Last accessed 16 February 2021)

EP3401400 - Methods and Compositions for RNA-Directed Target DNA Modification and for RNA-Directed Modulation of Transcription. https://register.epo.org/application? number $=\mathrm{EP} 18152360$ (Last accessed 16 February 2021)

EPO Technical Board of Appeal in Plant Genetic Systems/Glutamine synthetase inhibitors T356/93 [1995] EPOR 357

European Commission, Communication $(\mathrm{COM}(2000) 1$ final) on the Precautionary Principle: https://eur-lex.europa.eu/legal-content/EN/TXT/?uri=LEGISSUM\%3Al32042 (Last accessed 16 February 2021) 
Feldman R (2016) The CRISPR revolution: what editing human DNA reveals about the patent system's DNA. UCLA Law Rev Discourse 392:401

Global health ethics: Human Genome editing, World Health Organization: https://www.who.int/ ethics/topics/human-genome-editing/en/ (Last accessed 17 February 2021)

Guerrini C, Curnette M, Sherkow JS, Scott C (2017) The rose of ethical license. Nat Biotechnol $35: 22$

Hannah Mosby H (2018) Biotechnology's great divide: strengthening the relationship between patent law and bioethics in the age of CRISPR-Cas9. Minnesota J Law Sci Technol $19,2,565-604: 579$

Health is a fundamental human right. Statement by Dr Tedros Adhanom Ghebreyesus, WHO Director-General, 10 December 2017.: https://www.who.int/mediacentre/news/statements/ fundamental-human-right/en/ (last accessed 16 February 2021)

Hyde KJ, Schust DJ (2015) Genetic considerations in recurrent pregnancy loss. Cold Spring Harb Perspect Med, p 5

Ishino Y, Shinagawa H, Makino K et al (1987) Nucleotide sequence of the iap gene, responsible for alkaline phosphatase isozyme conversion in Escherichia coli and identification of the gene product. J Bacteriol 169:5429-5433)

Jinek M, Chylinski K, Fonfara I et al (2012) A programmable dual-RNA-guided DNA endonuclease in adaptive bacterial immunity. Science 337(6096):816

Jonietz E (2003) Choosing our children's genetic futures. Technol Rev (1 February 2003)

Kapterian G (2010) A critique of the WTO jurisprudence of 'necessity. Int Comp Law Q 59 (1):89-127

Kosicki M, Tomberg K, Bradley A (2018) Repair of double-strand breaks induced by CRISPRCas9 leads to large deletions and complex rearrangements. Nat Biotechnol 36:765

Lanphier E et al (2015) Don't edit the human germ line. Nature 519(7544):410-411; Leopoldina Nationale Akademie der Wissenschaften, The Opportunities and Limits of Genome Editing (2015) https://www.leopoldina.org/en/publications/detailview/publication/chancen-undgrenzen-des-genome-editing-2015/ (Last accessed 16 February 2021)

Matthews D (2010) Intellectual property rights, human rights and the right to health. In: Grosheide W (ed) Intellectual property rights and human rights: a paradox. Edward Elgar Publishing, pp $118-139$

Matthews D (2015) The right to health and patents. In Geiger C (ed) Research handbook on human rights and intellectual property. Edward Elgar Publishing pp 496-512

Matthews D, Brown A, Gambini E, McMahon A, Minssen T, Nordberg A, Sherkow JS, Wested, J, van Zimmeren E (2021) The role of patents and licensing in the governance of human genome editing: a white paper. Response to the WHO Expert Advisory Committee on Developing Global Standards for Governance and Oversight of Human Genome Editing Reports, Queen Mary Law Research Paper No. 354/2001

McMahon A (2020) Biotechnology, health and patents as private governance tools: the good, the bad and the potential for ugly? Intellect Prop Q 161

Mojica FJM, Juez G, Rodriguez-Valera F (1993) Transcription at different salinities of Haloferax mediterrane $i$ sequences adjacent to partially modified PstI sites. Mol Microbiol 9(3):613-21

National Academies of Sciences Human Genome Editing Initiative.: https://nationalacademies.org/ gene-editing/index.htm (Last accessed 17 February 2021)

National Human Genome Research Institute, Epigenomics Fact Sheet: https://www.genome.gov/ about-genomics/fact-sheets/Epigenomics-Fact-Sheet (Last accessed 16 February 2021)

National Institutes of Health (NIH), U.S. National Library of Medicine, Your Guide to Understanding Genetic Conditions: What Are Genome Editing and CRISPR-Cas9? https://ghr.nlm.nih.gov/ primer/genomicresearch/genomeediting (Last accessed 16 February 2021)

Noonan K (2019) CRISPR Interference Parties Propose Motions. Patent Docs Patent Law Blog, 1 August 2019: https://www.patentdocs.org/2019/08/crispr-interference-parties-proposemotions.html (Last accessed 16 February 2021) 
Nordberg A (2018) Patentability of human enhancement: from ethical dilemmas to legal (un)certainty. In: Pistorius $T$ (ed) Intellectual property perspectives on the regulation of new technologies. Edward Elgar, pp 54-92: 77

Nordberg A, Minssen T, Holm S, Horst M, Mortensen K, Møller BL (2018) Cutting edges and weaving threads in the gene editing (r)evolution: reconciling scientific progress with legal, ethical and social concerns. J Law Biosci 36-83:37

Normile D (2019) Chinese scientist who produced genetically altered babies sentenced to 3 years in jail. Science (December 30, 2019) https://www.sciencemag.org/news/2019/12/chinese-scien tist-who-produced-genetically-altered-babies-sentenced-3-years-jail. Accessed 22 Aug 2021

Nuffield Council on Bioethics (2018) Genome Editing and Human Reproduction: Social and Ethical Issues 7

Olivetti M (2010) Article 1: dignity. In: Mock W, Demuro G (eds) Human Rights in Europe: commentary on the charter of fundamental rights of the European Union. Carolina Academic Press, $\mathrm{p} 7$

Oviedo Convention and its Protocols, Council of Europe, opened for signature on 4 April 1997, Oviedo, Spain: https://www.coe.int/en/web/bioethics/oviedo-convention (Last accessed 16 February 2021)

Presentation by Feng Zhang (Broad Institute) at the Program on Science, Technology and Society Workshop on Editorial Aspirations: Human Integrity at the Frontiers of Biology, 26-28 April 2017, Harvard University

Presentation by Robin Lovell Badge (Francis Crick Institute, UK), member of the WHO expert advisory committee on developing global standards for governance and oversight of Human Genome editing at the Second Meeting of the International Commission on the Clinical Use of Human Germline Genome Editing, London, 14 November 2019. Available at: https:// royalsociety.org/topics-policy/projects/genetic-technologies/international-commission/ (Last accessed 17 February 2021)

Regalado A (2019) MIT Technology Review, December 3, 2019: https://www.technologyreview. com/s/614764/chinas-crispr-babies-read-exclusive-excerpts-he-jiankui-paper/ (Last accessed 16 February 2021)

Reich $\mathrm{J}$ et al (2015) Human genome surgery - towards a responsible evaluation of a new technology. Berlin-Brandenburg Academy of Sciences and Humanities (BBAW)

Reynolds G (2013) The precautionary principle and its application in the intellectual property context: towards a public domain assessment. In: Courtney Doaygoo B et al (eds) Intellectual property for the 21 st century: interdisciplinary approaches. Irwin Law, Toronto, p 95

Sadie G (2019) CRISPR's creatures: protecting wildlife in the age of genomic editing. J Environ Law 37:1

Salinas Alcaraz IC (2015) The concept of necessity under the GATT and national regulatory autonomy. Revista Virtual Via Inveniendi et Iudicandi (VIel) 10(2):77-99

Sandys A (2020) EPO Revokes Broad Institute Patent - But it's just the beginning for CRISPR-cas. JUVE Patent, 17 January 2020

Schellekens M, Vantsiouri P (2013) Patentability of human enhancements. Law Innov Technol 5 (2):190-213: 190 https://www.tandfonline.com/doi/abs/10.5235/17579961.5.2.190 (Last accessed 16 February 2021)

Schneider I (2019) Patent governance, ethics and democracy: how transparency and accountability norms are challenged by patents on stem cells, gametes and genome editing. In: Berg TC, Cholij R, Ravenscroft S (eds) Patents on life: religious, moral and social justice aspects of biotechnology and intellectual property. Cambridge University Press, pp 263-287

Sherkow JS (2017a) Patent protection for CRISPR: an ELSI review. J Law Biosci 565

Sherkow JS (2017b) CRISPR, patents, and the public health. Yale J Biol Med 90:667

Sherkow JS (2021) The CRISPR patent interference showdown is on: how did we get here and what comes next? Stanford Law School Law and Biosciences Blog: https://law.stanford.edu/2015/12/ 29/the-crispr-patent-interference-showdown-is-on-how-did-we-get-here-and-what-comes-next/ (Last accessed 16 February 2021) 
Sherkow JS, Thomas Scott C (2019) The pick-and shovel play: bioethics for gene-editing vector patents. North Carolina Law Rev 97:1497

Steinbock B (2008) Designer babies: choosing our children's genes. The Lancet (11 October 2008)

Sykora P, Caplan A (2017) The Council of Europe should not reaffirm the ban on germline genome editing in humans. EBMO Report 18(11):1871-1872

The National Academies of Sciences, Engineering and Medicine, Human Genome Editing: Science, Ethics and Governance, 2017, Consensus Study Report, 145

Tsung-Ling L (2019) Two Minutes to Midnight - What International Law Can Do About Genome Editing, 1

UNCTAD-ICTSD Project on IPRs and Sustainable Development (2005) Resource book on TRIPS and development. Cambridge University Press, p 378

UNESCO Declaration on Science and the Use of Scientific Knowledge (1999), Preamble, para. 19

Van Overwalle G, van Zimmeren E, Verbeure B, Matthijs G (2006) Models for facilitating access to patents on genetic inventions. Nat Rev Genet 7:143

WHO Launches Global Registry on Human Genome Editing, World Health Organization, 29 August 2019.: https://www.who.int/news-room/detail/29-08-2019-who-launches-globalregistry-on-human-genome-editing (Last accessed 17 February 2021)

Wojcik MH, Schwartz Inbar Yamin TS, Edward HL, Genetti CA, Towne MC, Agrawal PB (2018) Genetic disorders and mortality in infancy and early childhood: delayed diagnosis and missed opportunities. Genet Med, p 20

Zorrilla M, Yatsenko AN (2013) 'The Genetics of Infertility' Current Status in the Field, Current Genetic Medicine Reports, 1

Open Access This chapter is licensed under the terms of the Creative Commons Attribution 4.0 International License (http://creativecommons.org/licenses/by/4.0/), which permits use, sharing, adaptation, distribution and reproduction in any medium or format, as long as you give appropriate credit to the original author(s) and the source, provide a link to the Creative Commons license and indicate if changes were made.

The images or other third party material in this chapter are included in the chapter's Creative Commons license, unless indicated otherwise in a credit line to the material. If material is not included in the chapter's Creative Commons license and your intended use is not permitted by statutory regulation or exceeds the permitted use, you will need to obtain permission directly from the copyright holder.

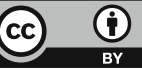

